књижевност - Језик и књижевност,

Модул књижевност

milan.grom@gmail.com

\title{
КАМИЈЕВ МЕРСО У КОНТЕКСТУ АПСУРДА И МЕТАФОРЕ ВАМПИРА - МЕТОДИЧКИ ПРИСТУП
}

АПСТРАКТ: У раду је дат један вид наставне интерпретације романа Странаи Албера Камија који укључује анализу главног лика у контексту филозофије апсурда и метафоре вампира. У уводном делу осветљен је контекст егзистенцијализма као филозофског правца и његовог упоришта у Камијевом роману. Приказана је компаративна анализа главног јунака у првом и другом делу романа, са посебним освртом на формално устројство преокрета својствено француској модернистичкој хорор причи и на мотив светлости који иницира причу о Мерсоу као вампиру новог доба. Систематизовано је приказан низ проблемских ситуација у којима се главни јунак налази и предложене су методе могуће анализе у настави. Рад укључује књижевнотеоријска разматрања Жан-Пол Сартра, Николе Милошевића и методичке компоненте неопходне за анализу књижевног дела у настави.

Кључне речи: Албер Ками, Странаи, Мерсо, апсурд, вампир.

\section{CAMUS' MEURSAULT IN THE CONTEXT OF ABSURD AND VAMPIRE METAPHOR - A METHODICAL APPROACH}

ABSTRACT: The paper presents one aspect of the teaching interpretation of Albert Camus' novel Stranger, which includes the analysis of the main character in the context of the philosophy of absurdity and vampire metaphors. In the introductory part, the context of existentialism as a philosophical direction and its foothold in Camus' novel are illuminated. A comparative analysis of the main character in the first and second parts of the novel is presented, with a special emphasis on the motif of light that initiates the story of Meursault as a vampire of the new age. A series of problem situations in which the main character is located and the proposed methods of possible analysis in teaching are systematically presented. The work includes literary theoretical reflections of Jean-Paul Sartre, Nikola Milošević, as well as the methodical components necessary for the analysis of literary work in teaching.

Keywords: Albert Camus, Stranger, Meursault, absurd, vampire. 
„Свест о апсурду, кад смо по први пут положили право на то да из ње изведемо правила понашања, учинила је да убиство изгледа као ствар према којој се може бити индиферентан. Ако ни у шта не верујемо, [...] онда је све могуће и ништа нема никаквог значаја. Не постоји за и против. Убиство није ни исправно, нити погрешно."

А. Ками, Побунени човек (1951)

\section{1. ЕГЗИСТЕНЦИЈАЛИЗАМ}

Уводни део прве, од укупно две наставне јединице колико је оптимално за анализу Камијевог дела у настави, најбоље је започети увођењем ученика у постулате савремене књижевности, као и одређењем феномена егзистенције и егзистенцијализма. Узајамним давањем коментара (дијалошком наставном методом) на унапред прочитани текст о савременој књижевности из школске Читанке (Николић - Милић 2007: 117-118) можемо доћи до основних сазнања о наведеним феноменима. На првом школском часу користимо индивидуални облик рада, a на другом комбинацију индивидуалног и групног рада. Историјски оквир егзистенцијализма као струје у књижевности и положај дела Албера Камија у том контексту, као и основне био-библиографске црте аутора, потребно је обрадити текст методом, односно поделом наставних листића са фрагментима из одабраних извора ученицима, са напоменом да поједини ученици могу одабрати тему реферата из секундарне литературе (принцип индивидуализације и принцип прилагођености наставе узрасту ученика).

Наставну интерпретацију романа Странац започињемо уводним излагањем о егзистенцијализму. У савременој књижевности запажамо појаву различитих праваца, струја или такозваних „изама”, попут раније насталог експресионизма или надреализма, али и нове „изме” као што је социјалистички реализам, егзистенцијализам и др. Албер Ками са својим капиталним романом апсурда Странац и са рационалним објашњењем филозофије апсурда у делу Mum o Cuзифу припада струји егзистенцијализма. Шире посматрано егзистенцијализам јесте филозофски и књижевни феномен:

„Корени овог правца у књижевности сежу дубоко у антику, где се егзистенцијалистички елементи мишљења назиру у делима Сократа и Платона, а касније и код стоичара попут Св. Августина, Паскала и др. Модерни егзистенцијализам почиње са Кјеркегором, Хајдегером и Јасперсом, док егзистенцијалистима, у правом смислу речи, можемо 
сматрати Жан-Пол Сартра, Мерло-Понтија и Албера Камија. Егзистенцијализам полази од различитих питања: егзистенције човека као изгубљене јединке у отуђеном свету; опстанка света; опстанка књижевности уопште, док је главно питање: да ли егзистенција претходи есенцији, односно, да ли биће (материјално), претходи суштини или обрнуто" (Живковић 1985: 157-158).

Од свих филозофа ове оријентације нарочито се издваја Жан-Пол Сартр који је радикализовао систем егзистенцијализма и уобличио га, а затим га успешно интерполирао у позориште и књижевност. ${ }^{1}$ Сартр очекује од модерног писца непрестану ангажованост и одговорност за судбину света. Како би писац стварао у складу са епохом, неопходно је да се социјално ангажује и настави традицију Волтера и Жида, залажући се за суштинска питања времена. У својој студији Шта је књижевност Сартр расправља о њеној функцији. Залаже се за егзистенцију саме књижевности као неке врсте „хигијене” света која сузбија сву „корозију” људскога духа, попут буржоазности. Жан-Пол Сартр најпре ће ступити у полемику са Камијем, назвати га судијом који напада концепцију људске слободе засноване на марксистичким начелима, јер се Ками залаже за потпуну слободу човекове „природе”, што потврђује његов исказ из поменуте полемике: „Човек је у потпуности човек када је срећан”. ${ }^{2}$ Сартр ће замерити Камију да се залаже за неефикасни морал „лепе душе”, јер је према његовом схватању срећа ништа друго до склад човека и његове егзистенције, при чему је човек биће, али и предмет у својој социјалној потлачености. ${ }^{3}$ Познато је и Сартрово схватање Камијевог хуманизма, где се говори о човековом ставу према смрти која изненађује: „Нељудска нужда умирања неминовна је, а Камијев рад је чист и победоносни покушај једног човека, да сваки тренутак свога постојања преотме од своје будуће смрти". ${ }^{4}$ У дијалогу са ученицима користимо следећа питања: Како разумемо појам егзистенција / егзистенцијализам? На шта нас асоцира термин апсурд? Знамо ли шта у књижевности означава нихилизам?

\footnotetext{
${ }^{1}$ Види: Jean-Paul Sartre, Egzistencijalizam je humanizam, „Veselin Masleša”, Sarajevo, 1964.

2 У сврху корелативног приступа настави на овом месту може се напоменути да се питањем среће бави и С. Бекет у антидрами Чекајући Годоа, у сцени када Владимир пита Дечака који служи код Годоа, да ли му је добро код њега и да ли је срећан, на шта он одговара да не зна. Владимир потом потврђује да се и сам исто осећа. Ово је показатељ да је питање егзистенције човека неминовно повезано са питањем људске среће у читавом корпусу тзв. „антикњижевности” или „књижевности апсурда”.

${ }^{3}$ Види: Жан-Пол Сартр, „Одговор Алберу Камију”, у: Портрети, Нолит, Београд, 1981.

${ }^{4}$ Види: Жан-Пол Сартр, „Албер Ками”, у: Портрети, Нолит, Београд, 1981.
} 
Наведите везе филозофије и књижевности? Уочавамо ли неку везу тог типа након читања романа Странац?

\section{2. АНТИРОМАН И КАМИЈЕВА ФИЛОЗОФИЈА АПСУРДА}

Карактеристике антиромана разликују се од устаљене форме и садржине романа по супротности, па тако епска прича бива потиснута у други план, а до изражаја долазе есејистички и медитативно-лирски елементи дела. Термин антироман настао је по узору на појам антидраме, где се нарочито издваја Семјуел Бекет са својим делом Чекајући Годоа. Општа карактеристика ових дела јесте снажан осећај апсурдности живота пуног бесмисла и ништавила који је као такав доследно осветљен. Како је већ уочено, Камијев антироман својеврсна је парабола, структурално сложенија и са више значења од традиционалних параболичних књижевних форми. Фабула Камијевог дела разликује се од фабуле класичне параболе, која је по правилу „невероватна”, док је у Страниу реч о „вероватном” типу радње. Албер Ками такође оставља читаоцу на вољу да самостално извуче закључке из дела, док то није случај са класичном параболом. Једини коментар који је Ками оставио јесте медитативно-лирска проза Muт о Сизифу, где можемо уочити покушај рационалног приближавања истог оног искуства апсурда, које је уобличено у роману Странац.

Комплексна филозофија апсурда у Страниу најуочљивија је у карактеризацији главног јунака Мерсоа, где до изражаја долази равнодушност и апсурдност његове егзистенције у савременом свету. Сартр сматра да је Мерсо отелотворење апсурда и сви његови доживљаји и поступци јесу истицање немирења са устројствима света који нема смисла. Апсурдни човек Мерсо не види себе као карику у колективу - ни друштвену, ни породичну, крајње је неодговоран како за своје поступке тако и за своја осећања према свему што га окружује; у потпуности је одсутан и отуђен, странац за себе и за друге. Камијева идеја филозофије апсурда преточена је у живот и судбину једног човека и бива конкретизована кроз приказивање свакодневице напетог односа асоцијалне јединке и друштва. Аутор у предговору америчког издања Страниа каже неколико речи о својој „филозофији апсурда”, отелотвореној кроз лик Мерсоа:

„Мерсо је човек који одбија да учествује у друштвеној игри, одбија да лаже, и друштво се због тога осећа угроженим. У нашем друштву човек који не плаче на сахрани своје мајке вероватно ће бити осуђен на смрт" (Ками 2009: $8-9)$. 
Рацио сваког човека може доћи у стадијум спознаје људске несавршености и у непрестану тежњу за достизањем исте, али у том тренутку, Камијевом идејом вођени, не смемо дозволити душевни пад у индиферентност, већ морамо ступити у револт и „бацити се” на дуг и исцрпни животни „посао” попут Сизифовог.

Као што смо већ напоменули, Mum o Сизифу јесте својеврстан филозофски коментар Странца, а као основне ставове Камијеве филозофије апсурда Никола Милошевић наводи следеће:

„Апсурд као такав егзистира једино у узајамној присутности човека и апсурда; стил писања је крајње сув и безличан; присутан је непремостиви јаз између човека и света; људи постају странци због узалудне носталгије за апсолутним; последица ове филозофије јесте потпуна равноправност апсолутно свих поступака, где не постоји црно-бело расуђивање о добром и лошем, већ само свест о апсурду” [курзив Н. М.] (Милошевић 1990: 192230).

О карактеристикама романа апсурда и књижевности апсурда уопште, као и о основним постулатима Камијеве филозофије апсурда, неминовно се мора говорити у монологу (монолошком наставном методом), јер је реч о новом и неуобичајеном феномену у књижевности, са каквим се ученици нису сусретали раније. Непосредно пре уласка у фронтално излагање о феномену романа апсурда важно је поставити неколико проблемских питања о значењу апсурда и апсурдног уопште, које се јавља у свакодневном животу.

Лик Мерсоа јесте својеврсно литерарно исходиште филозофије апсурда Албера Камија, а бесмисленост и сизифовску узалудност његовог живота можемо узети као средишњу тему дела. Уколико делу приступимо из угла биографског метода проучавања књижевности (који није увек немогућ и баналан) могуће је у једном сегменту упоредити главног јунака дела са аутором. Из историје је познато да је Алжир био француска колонија, а затим и интегрални део Француске, све до 1962. године када постаје независна држава. Албер Ками је живео у, са становишта културе, „француском” Алжиру један просечан чиновнички живот, баш онакав какав Мерсо води. Осим ове чињенице која нас упућује на аутора који из личног искуства познаје друштвене односе у једној медитеранској земљи препуној сунца и светлости, тешко је говорити о Странцу као о правој литерарној исповести. Наиме, за расветљавање дубљих поетичких инстанци у роману Странац није довољно користити се пишчевом биографијом, која није занемарљива, већ је важно усредсредити се на вишеслојност књижевног текста који садржи и пишчев низ порука упућених читаоцу. На читаоцу је да у тим порукама 
разабере и одлучи се за смер анализе. У овом раду дат је преглед појединих поетичких сигнала утканих у структуру дела, због чега је и предложена интерпретација заснована на структуралистичком читању и поетици рецепције. На основу уочене „књижевне комуникације” могуће је отворити спектар нових тумачења:

„, [..] проучавање односа између датог књижевног дела и у њега уграђеног такозваног хоризонта очекивања пошиљаоца (његова схватања естетских и идејних очекивања реципијента) и функционисања тога дела у перцептивним ситуацијама које се временом мењају” (Bužinjska - Markovski 2009: 321).

Извесно је да Ками припада врху мајстора француске прозе, а романескна форма за коју се одлучио ближа је поетичким закономерностима француске кратке приче у којима се збијеношћу и језгровитошћу израза оставља простор за читаоца (примаоца) и његово заједничко делање са писцем у довршавању поетичких исходишта предметног света дела: „Новеле захтевају више интелектуалне активности. [..] Често треба сами да замислимо декор, да откријемо неречено, понекад у следећој фази да интерпретирамо, штавише да измислимо пад или могућа продужења" (Zimerman 1988: 7). Друго поетичко исходиште француске кратке приче јесте изненадни преокрет какав срећемо у Камијевом роману на прелазу из првог у други део: „Насупрот причама које сами треба да реконструишемо или довршимо, бројне су приче кружног временског тока које се затварају саме над собом, непредвиђеним мопасановским завршетком. Оне често својом конструкцијом скрећу читаоца на погрешне стазе, да би га на крају грубо вратиле на оно што је битно" (Cakeljić 1988: 197). Наиме, први пишчев хоризонт очекивања наводи нас на мишљење да је Мерсо „човек међу људима", док у другом делу видимо да је у питању љуштура лишена људског, јединка из неког заумног, оностраног света. Нарочито је интересантно да су најбољи неочекивани преокрети особеност француске хорор приче, као нпр. приче Ани Симон. Ипак, код Камија нећемо срести хорор, већ само метафору вампира обојену филозофијом апсурда.

Роман се састоји, како је већ истакнуто, од два, у интерпретативном смислу, супротстављена дела. Главног јунака из првог тешко је препознати у њему самом у другом делу. По свему судећи више није исти карактер у питању. Нагли обрт и заокрет од статике ка динамици отвара могућност пажљиве анализе у наставној пракси. Методичком рашчлањавању Камијевог дела приступамо преко осветљавања карактера главног лика у првом и у другом делу романа. Роман је компонован низом догађаја постављених у узрочно-последичном редоследу који успоставља приповедање у првом лицу 
главног јунака, односно његов језик каузалности. Увођење ученика у дело потребно је остварити интерпретативно-аналитичким системом наставе, али и са повременим инсистирањем на индивидуалном облику рада, при чему ће ученици проналазити делове текста потребне за интерпретацију дела.

Кроз дијалог о усложњеном карактеру главног јунака који само подсећа на вампира (а управо то „подсећање” је главни савезник наставника у одгонетању његове сложености!) ученици отварају могућности његовог дефинисања. Користимо нека од следећих питања и пратимо ток дијалога подпитањима: У чему се Мерсо разликује у првом и у другом делу романа? Има ли промена у његовом начину делања? Запажамо ли промену у односу према свету кроз његово опхођење према другим јунацима? Закључујемо од каквих карактерних пасажа је саткан Мерсо, а затим сазнања надограђујемо систематичном интерпретацијом првог и другог дела књиге.

\section{3. ЛИК МЕРСОА У ПРВОМ ДЕЛУ РОМАНА}

Читалац упознаје Мерсоов карактер већ на првим страницама књиге. Сугеришући његов крајње хладан однос према смрти своје мајке, аутор нам првим реченицама саопштава шта је то апсурдни човек. Мерсо није сигуран када му је мајка преминула и двоуми се између два одговора: „данас” или ,јуче”, док за комплетну церемонију сахране каже: „Све се одиграло брзо, сигурно и природно, па се више ничег и не сећам". У разговору са љубавницом Маријом Кардоном јавља се први наговештај проблема кривице у психологији главног јунака који ће у другом делу романа бити знатно разрађенији. Мерсо иде на купање и у биоскоп да гледа комичне филмове са љубавницом, само дан после смрти своје мајке, а једини оправдавајући одговор који на то даје је следећи: „Сваки човек је увек по мало крив”. Апсурдност Мерсоовог гледања на свет долази до изражаја и када свом пријатељу Ремону Сентесу каже да уопште није одвратно што старац Саламан свакога дана туче свог пса. Филозофија апсурда отелотворена у главном јунаку дела дотакла се и проблема вере, у призору који Мерсо запажа у Ремоновој соби, где су изнад кревета једно поред другог окачене слике голих жена и хришћанска гипсана фигура анђела. Систем моралних вредности које Мерсоово око апсурда види у једном тренутку поистовећује се са гледиштем из угла моралног дна. То становиште упитне етике у делу заступа подводач Ремон који жели да добро казни проститутку, јер она за себе тражи велики проценат, а још и ради „са стране”. Мерсоово подржавање казне у овом случају потврђује тезу о његовом моралном посрнућу, али нам и 
осветљава став главног јунака према чину кажњавања појединца, којем ће и сам на неки начин бити подвргнут.

Облик казивања који уоквирује Мерсоове ставове јесте језик каузалности, где се изражавају само узрок и последица, „а традиционално приповедање у првом лицу говори о свему, осим о самоспознаји главног јунака" (Милутиновић 2009: 7-9). Из односа према другим ликовима у делу можемо доћи до бољег увида у Мерсоов карактер, али и у његов однос према свету и колективној свести друштва. Када га Марија пита да ли је воли, он ће јој одговорити да му се „чини” да је не воли, али и да изјава „волим те” ништа не значи. ${ }^{5}$ Оштрица Камијеве филозофије апсурда позабавила се и феноменом љубави, при чему је значење лексеме ,љубав” проблематизовано и доведено у иронијски контекст. У питању је реч која би овде могла да буде само лажна и сувишна, јер је као таква само резултат одавно утврђене употребне навике друштва, навикнутог на поједине фразе, а не на искрен излив осећања. Овде апсурд заузима место залога искрености и разбијања баналних празнословља и лажног морала.

У првом делу романа постоји и осветљавање главног јунака из једног другог, крајње хуманистичког угла. На тај начин читаоци стичу утисак да је реч о једном позитивном јунаку. Ово место у делу од нарочитог је значаја за изградњу утиска о Мерсоу у другом делу књиге. Тезу потврђујемо примером у којем, када Мерсо чује плач старца Саламана у суседној соби због губитка свог пса, изговара необичну реченицу: „Не знам зашто, али помислио сам на своју мајку". Овде је реч о једној нејасној и недореченој интервенцији аутора, где је присутна назнака о осећању бола због властитог губитка, чиме Мерсоова равнодушност бива доведена у питање. Све је остало на нивоу назнаке, без подробнијег објашњења ове необичне и недокучиве карактерне стране крајње ,апсурдног човека”. У питању је хоризонт очекивања пошиљаоца који оставља простор за херменеутички приступ делу. Приликом постепеног установљавања, условно речено, позитивних и негативних црта које поседује главни лик романа, пожељно је да пред ученицима поставимо проблемску ситуацију (проблемско-стваралачки систем) у вези са усложњавањем његовог карактера, тј. да укажемо на немогућност сврставања

\footnotetext{
${ }^{5}$ Мерсо јасно зна шта не воли и шта му не прија, па и у овом исказу ће рећи да полицајце „сигурно” не воли, а за све ствари које би изван света и свемоћне ауре апсурда један човек требало да воли и поштује, Мерсо ће рећи „да му се чини”, „да није сигуран” или „да не зна зашто, али помислио је”. Овим језичким конструкцијама осликан је начин на који функционише расуђивање о свим хуманистичким и цивилизацијским вредностима у Странцу.
} 
Мерсоа у црно-белу категорију добрих и лоших ликова проистеклу из реалистичког приповедања.

Релевантна и пожељна је и могућност организовања дебате између две групе ученика, где се рад једне групе усмерава на потенцијално добре особине главног јунака, а рад друге на негативне карактерне црте, после чега можемо доћи до дефинисања типа човека који поседује апсурд, као једину свест и апсолутну негативност према свим странама живота и према свему што живот нуди.

Овај прворазредни представник апсурдног погледа на свет у потпуности се не слаже са амбициозношћу и са било којим видом промене и напредовања ка бољем, према здраворазумској динамици живота. Мерсоов аргумент против амбиције крајње је једноставан, о чему сведочи и пример када на понуду свог послодавца за премештај на боље радно место, у Париз, одговара да његов живот није несрећан, па нема потребе да га мења. Из текста сазнајемо и чињеницу да је последњи Мерсоов сусрет са амбицијама био у студентским данима, али ће за све то тврдити да је било погрешно и узалудно. Главни јунак гаји неки вид антагонизма према традиционалној концепцији брака и породице, а својој љубавници Марији каже да је све то „неозбиљно”. Интересантно је и то да Мерсо не воли ни ондашњи Париз, јер у њему људи имају белу кожу, што је притајени уплив Камијевог антинацистичког политичког ангажмана, приказаног у делу Писма немачком nријатељу.

У низу наведених примера показали смо Мерсоов психолошки, морални и социјални вид одсутности и отуђености од света и друштва. На једном месту у првом делу романа видимо да је овде реч о свету који је у потпуности аутоматизован и механички, па је то један од разлога Мерсоове отуђености и осећаја „странца” у њему. Главни јунак, док руча у ресторану код свог пријатеља Селеста, уочава једну ситну жену која систематично поручује све из јеловника, а затим и све то крајње ,роботски” и ужурбано једе. Врхунац аутоматизма у свету који окружује Мерсоа јесте систематично и са пуном и једнаком пажњом бележење готово свих радио-емисија у радиопрограму за текућу недељу, од стране поменуте чудне жене.

\section{4. КОНТЕКСТ МЕТАФОРЕ ВАМПИРА}

Нагли и изненађујући фабуларни заокрет, какав срећемо у хорор причи француског модернизма, чини потку другог дела романа. Када упозна Мерсоа читалац ствара слику реалистичког јунака који демистификује свет 
страхова и сваку људску духовност (нематеријалност) боји хладнокрвним апсурдом. Мерсо је након заокрета у причи измештен из позиције какву заузимају јунаци реалистичке прозе. Психички одсуствује из реалних околности које су га задесиле и своју егзистенцију види у другом свету. Из природе догађаја померен је у натприродно окружење које подсећа на фантастику. Основне карактеристике фантастике, као што је отклон од мимезиса као стваралачког исхода и неједнак однос према постојећим миметичким моделима стваралаштва просијавају кроз Мерсоов лик. У питању је тип уметничког стваралаштва који Платон назива phantastike што је супротност мимезису. ${ }^{6}$ Процес демистификације из првог дела је напуштен, а главни јунак ће постати део симболичке, мистификоване равни дела. Све што он ради након своје метаморфозе јесте одлика појединца који себе више не види међу људима и који одлучује да оде на неко за њега боље место - у простор сигурне егзистенције. Питање је да ли би књижевност могла постојати без удела мистификације: „Да нема мистификовања књижевност би била битно осиромашена. Тешко да би уопште и постојала. Нема такозване голе књижевности" (Аћин 2011: 14). Мерсо ће добити свог двојника који се води законима натприроде, једним системом вредности непознатом хуманистичком погледу на свет. Двојник ће преузети улогу главног јунака и самостално наставити да дела; са њим нема комуникације каква је заступљена код јунака Борхесове Къиге од песка.

Време у првом делу романа траје свега неколико дана, а као најдоминантнији мотив у делу издваја се светлост. Мерсоу светлост и летња врућина не пријају од самог почетка дела, што потврђује присуство мотива светлости у опису летње жеге и врућине на првој страници књиге. Прву ноћ у роману Мерсо је провео под упаљеним светлом које му је много сметало у једној просторији у старачком дому, у којој је био ковчег његове преминуле мајке. То је морао поднети на једвите јаде, јер поред поменуте хладнокрвности и равнодушности није смео отићи толико далеко са својом неодговорношћу да напусти просторију.

Дан када Мерсо борави са својим пријатељима на плажи главна је прекретница у делу, јер управо се тада дешава централни догађај - Мерсоово убиство Арапина. Увод у догађај приказан је сведеном дескрипцијом, тј.

${ }^{6}$ Види: Јовица Аћин, Паукова политика: за критику књижевне метафизике, Просвета, Београд, 1978. 
мотивом снажне и неподношљиве светлости ${ }^{7}$, која је, у том тренутку, главни узрок кризне ситуације усмерене ка извршењу злочина. Мерсоу светлост претерано смета и према њој се односи крајње опсесивно. Нарочита узнемиреност због светлости код главног јунака присутна је све до почињавања злочина, који му је симболички „спрао” тај терет. Мерсо је на ивици издржљивости због овог проблема, што видимо у једном од бројних констатација: „Сунце је падало на песак готово окомито и његов бљесак на морској површини био је неиздржив; сунце клизну по револверу”, итд.

Мерсо ће се осетити веома узнемирено и рећи ће да не верује у Бога када испред њега јавни тужилац извади Исусово распеће у другом делу књиге, после чега ће га истражитељи ословљавати именом Антихрист. Мерсоови страхови од светлости и од крста, као и жеља за крвљу (испаљивањем додатних пуцњева у беживотно Арапиново тело), могу се протумачити као карактеристике савременог вампира, који је вешто скривен непотпуним описом његових унутрашњих психолошких стања. Разуме се, само на нивоу метафоре која нам помаже у наставној интерпретацији дела.

Камијев вампиризам узимамо као мотивациони пример за анализу мотива сунца, односно топлоте и светлости уопште, који је један од кључних за осветљавање карактера главног јунака - Антихриста, као и за приближавање узрока због којег он пуца у човека. Наведени одломци, као и издвојени фрагменти текста из наредног поглавља које ученици треба сами да пронађу, могу нам послужити као сараднички императив, после чега дијалогом долазимо до осветљавања мотива сунца и Мерсоовог „вампирског” односа према светлости изопштене из света апсурдности.

\section{5. НЕОПХОДНОСТ ИЗВРШЕЊА ЗЛОЧИНА - БЕГ ИЗ ВРЕЛЕ СВЕТЛОСТИ У СПАСОНОСНУ ТАМУ}

Скраћени традиционални идилични пејзаж у делу употребљен је у маниру већ поменутог поступка Камијеве филозофије апсурда. Апсурд простора огледа се у томе што кратко описани амбијент летње идиле - плажа, сунце, жубор воде и три тона из фруле Арапина, доводе до потпуно неуравнотеженог деловања актера романа. Најпре Ремон вади револвер са намером да убије Арапина, у чему га Мерсо спречава, али док је узимао

\footnotetext{
7 „Дан већ препун сунца, деловао је на мене као шамар” - један од бројних примера где је светлост приказана као неподношљива.
} 
револвер јака светлост је склизнула и у њему пробудила већ поменуту вампирски обојену фобију и немир. Све то га је навело да се одлучи за некакву новохамлетовску мисао „и пуцати и не пуцати”, која је апсурдна варијанта Хамлетове „бити или не бити”. 8 Касније ће Мерсо на истом овом месту, али нешто другачије описаном, извршити злочин.

Главни јунак шета плажом, физички угрожен ${ }^{9}$ врућином и светлошћу:

„Чело ми је набрекло од сунца. [...] Жега ме притиска и смета ми да корачам. [...] При сваком мачу светлости, који је искрсавао из песка, из побелеле шкољке или из комадића стакла, вилице су ми се грчиле. [...] Дуго сам тако ишао” (Ками 2009: 47).

Потом долази до места на којем ће извршити убиство, али тада видимо једну измештену естетику, потпуно другачији призор оног идиличног извора на плажи, што је у функцији наговештаја догађаја који ће уследити: „Громада стене окружена прстеном заслепљујуће светлости и морске прашине" (Ками 2009: 48). Мерсо на извору среће Арапина који лежи тако да му је глава у сенци ${ }^{10}$ и ужива, што је потпуно супротно осећању главног јунака који жуди за бегом из светлости и тегобе проузроковане њоме.

Важно је поменути и мотив мора на овом месту у делу, јер га Мерсо такође доживљава као мору која га наводи на неминовност извршења злочина: „Шум таласа био је још тромији, још тиши него у подне [...] ваздух ужарен” (Ками 2009: 48). Мерсоов демон светлости у његовој перцепцији света активно делује и наводи га на злочин. Када му се од одсјаја Арапиновог ножа учини да је то оштрица која лети право према њему, због чега ће одреаговати афективно и испалити први „невини” пуцањ: „Светлост је шикнула са челика и као какво дуго блиставо сечиво погодила ме у чело. Тада се све зањихало. Са мора се докотрљао густ и усијан дах" (Ками 2009: 50). Мерсо је у потпуности пореметио равнотежу дана и тихе плаже на којој је, наводно, био срећан, и првим хицем успешно је ,стресао са себе зној и

\footnotetext{
${ }^{8}$ Мерсоа можемо посматрати и као Хамлета новог доба који заступа девизу: „И бити и не бити”, јер је равнодушан и свеједно му је како ће делати и шта ће бити последица тог деловања.

${ }^{9}$ Треба имати у виду да Мерсо шета плажом у капуту, што сазнајемо у тренутку када извршава убиство, па није искључено да и његов физички изглед, као интервенција самог аутора бива подређен законима филозофије апсурда.

10 Карактеристично за Мерсоове потенцијалне противнике у делу управо је то што су заштићени од његовог највећег непријатеља - светлости, што потврђује и пример из другог дела романа када је приликом саслушања Мерсо изложен светлости лампе, а јавни тужилац седи ван њеног домашаја, у сфери мрака, који је за Мерсоа својеврсни спокој.
} 
сунце", како сам тврди. Почетак његове коби отворила су остала четири „крвава” пуцња у беживотно тело Арапина - „Четири кратка куцња на врата несреће".

Издвајањем појединих феномена из првог дела романа долазимо до оног закључног - самог чина злочина, који нас води за степеник дубље у предметни свет Камијевог дела, али и есенције филозофије апсурда. После проблемске ситуације која се тицала Мерсоа као условно доброг/лошег, односно апсурдног лика унутар света дела, долазимо до још једног уплива проблемске наставе као погодног решења за обраду новонасталог проблема убиства. Проблем који постављамо ученицима базира се на три питања:

\footnotetext{
$\checkmark$ Зашто је неопходно да Мерсо изврши злочин (мотив мора и сунца)?

$\checkmark$ Да ли је то оправдано (самоодбрана и сл.)?

$\checkmark$ Зашто убија непознатог човека (са укупно пет хитаца „1+4”)?
}

\section{6. ЛИК МЕРСОА У ДРУГОМ ДЕЛУ РОМАНА}

На почетку другог дела романа највише треба обратити пажњу на предмет истраге, односно на Мерсоов морал. У „природним” ${ }^{11}$ околностима романа, изван Камијеве филозофије апсурда, суђење би требало да буде усмерено према злочину који је почињен. Међутим, у роману је истрага са осудом и мржњом усмерена на анализу Мерсоових осећања, како би био доведен на врх „социјалне гиљотине” у коју се свесно уплео. У разговору са додељеним адвокатом главни јунак нам открива своје виђење света, где је најдоминантнији узрочно-последични пар физичке потребе / емоције. Физичке потребе главни су узрок и кривац за ометеност Мерсоових осећања, па сходно томе није чудно што је безосећајан на погребу своје мајке, јер је био топао и за њега неподношљив летњи дан. На питање да ли му је било тешко на дан погреба своје мајке, Мерсо одговара у маниру већ познате дефиниције љубави из првог дела романа, када је у питању била љубав према Марији, али са додатно продубљеним апсурдом: „Свакако, маму сам много волео, али то ништа не значи. Сва здрава људска бића прижељкивала су мање-више смрт оних које воле" (Ками 2009: 54). На овај начин Мерсо са

\footnotetext{
11 Термин је употребљен у значењу реалистичког схватања романа као жанра, који је устаљен у знању и књижевном искуству ученика.
} 
адвокатом припрема своју „одбрану”, да би га потом пожелео уверити да је „исти као и сви други људи”.

Проблему својеврсне безосећајности главног јунака и тврдњи да је исти као остали можемо приступити дијалошком наставном методом, где би ученици у дијалогу са наставником дошли до ближег одређивања човека апсурда и његових сличности и разлика, у односу на друге људе уопште. ${ }^{12}$ Индивидуални облик рада у овом случају је примаран, јер се од ученика очекује да сами и уз подстицаје наставника изведу закључке из Мерсоових изјава адвокату и тужиоцу, у циљу одговора на питање: суди ли се Мерсоу за почињени злочин или за морал, хладнокрвност и др.?

\section{7. ПРОБЛЕМ КРИВИЦЕ}

Главни проблем у другом делу Камијевог Странца јесте проблем кривице. На крају претходне наставне јединице ученицима задајемо припремне задатке који ће се односити на уочавање проблема кривице у другом делу романа и реферисање о истом феномену. Мерсоов однос према кривици је такав да је уопште не види као проблем и у разговору са истражним судијом осећа нелагодност, а не кајање. После изјаве да не верује у Бога и након сведочења многих у корист осуде његовог морала, где ће га назвати Антихристом и моралним чудовиштем, Мерсоу је једино преостало да пожели да заплаче, јер га баш сви мрзе. На овој проблемској ситуацији можемо се задржати организовањем кратке дебате, где је неопходно осветлити положај угрожене јединке у друштву. Проблем се актуелизује и пореди са данашњим осудама друштва и осећањима отуђења јединке.

Мерсо после смртне пресуде једино жели да умакне неминовном деловању механизма који „меље” оно хумано у човеку. Јавља се снажна потрага за излазом из неизбежности и нада једног човека за „брзом” смрћу (док буде бежао да га погоди зрно метка), али ту врсту „луксуза” механизам настоји да човеку ускрати и у потпуности укине.

Главни јунак непрестано размишља о проблему смрти и о чину јавног погубљења, који назива „затрованом радошћу”. Као један од проблема Мерсо истиче немогућност нове шансе за живот. За боље осветљење овог феномена можемо искористити сродни садржај - филм Лазарус пројекат, у којем људи

\footnotetext{
12 Мисли се на особине човека из реалног света, који није захваћен „деловањем” филозофије апсурда.
} 
добијају нову шансу и нов живот, али у изолованом свету у којем постају много већи „странци” (корелацијско-интеграцијски систем). Поред враћања на проблем љубави, Мерсо се изнова бави и проблемом среће који смо такође поменули у анализи првог дела Странц̧а, па се компаративним освртом увек можемо поставити дубље у предметност Камијевог дела (принцип систематичности и поступности, обнављање градива из претходне наставне јединице). После тврдње да човек никада није у потпуности несрећан, Мерсо ће нам појаснити шта је то смрт, тако што ће нихилистички дефинисати живот:

„Сви знају да живот није вредно живети. Није важно да ли ће човек умрети у тридесетој или у седамдесетој години живота, у оба случаја други људи и друге жене живеће хиљадама година" (Ками 2009: 93).

\section{8. МЕРСООВ ОДНОС ПРЕМА СМРТИ И БОГУ}

У разговору са свештеником Мерсо ће рећи да га је осудила људска, а не божанска правда, са којом нема ништа, а у зидовима ћелије не види лице Бога, већ лице боје сунца и са пламеном жудње - Маријино лице. Мерсо тврди да је потпуно сигуран и да „зна” зашто се директно противи свештениковом „надању” и „веровању”. За главног јунака Камијевог дела време проведено уз Бога је изгубљено време, а свештеник му ни у једном погледу није „отац”, како га други називају, већ је у истој равни са осталим људима, па ће доћи ред да и њега осуде. Ипак, не можемо рећи да је овај Мерсоов антагонизам према Богу поткрепљен и његовим унутрашњим миром, јер у њему све кључа од узнемирености. Ову тезу потврђују редови који су врхунац „Антихристовог” немира: „Ја сам био у праву, и сад сам у праву, одувек сам у праву”.

У последњим данима живота Мерсоов једини контакт са светом јесте прозор ћелије кроз који он види само сунце и море, а у зору чује једино трубе бродова. Последње јутро у његовом животу ове трубе нису се огласиле и нису га опоменуле на свет у којем је постао индиферентан. Само себи својственом вампиру Џон Донова звона не звоне, јер његово распеће неће гледати мноштво гледалаца са повицима мржње, као што је сам пожелео, па самим тим његов апсурдни живот у ,људском механизму” неће бити третиран као отцепљење дела острва човечанства, које је сачињено од живота јединки. Људски живот овде је обесмишљен, а када апсурд узме своју џелатску оштрицу над његовим гашењем нема Бога, а ни посмртних звона. 
Интерпретација романа Странаи Албера Камија, која укључује анализу главног лика у контексту филозофије апсурда и метафоре вампира, погодно је полазиште за даља читања дела савремене светске књижевности. Отварање детаљног уочавања појединих мотива ствара могућност шире рецепције дела и потраге за његовим ређе разматраним слојевима. Пажљивом деконструкцијом тематско-мотивске структуре читалац уграђује себе у поруку и функцију књижевног дела у другачијем, помереном контексту.

\section{ЛИТЕРАТУРА}

Аћин, J. (1978). Паукова политика: за критику кьижевне метафизике. Београд: Просвета [Aćin, J. (1978). Paukova politika: za kritiku književne metafizike. Beograd: Prosveta].

Аћин, J. (2011). Голи приповедач: поетика за екстрареалистичко приповедағе. Београд: Службени гласник [Aćin, J. (2011). Goli pripovedač: poetika za ekstrarealističko pripovedanje. Beograd: Službeni glasnik].

Bužinjska, A., Markovski, M. P. (2009). Književne teorije XX veka. Beograd: Službeni glasnik.

Димић, И. (1970). Приступ романима Албера Камија. Београд: Научна књига [Dimić, I. (1970). Pristup romanima Albera Kamija. Beograd: Naučna knjiga].

Живковић, Д. (1985). Речник књижевних термина. Београд: Нолит [Živković, D. (1985). Rečnik književnih termina. Beograd: Nolit].

Zimerman, D. (1988). „Fransuska novela”, u Antologija kratke priče Francuske (prir. V. Cakeljić). Kruševac: Bagdala: 5-8.

Илић, П. (2003). Српски језик и књижевност у наставној теорији и пракси. Београд: Змај [Ilić, P. (2003). Srpski jezik i književnost u nastavnoj teoriji i praksi. Beograd: Zmaj].

Ками, А. (2009). Странаи. Београд: Завод за уџбенике и наставна средства [Kami, A. (2009). Stranac. Beograd: Zavod za udžbenike i nastavna sredstva].

Милошевић, Н. (1965). Негативни јунак. Београд: Просвета [Milošević, N. (1965). Negativni junak. Beograd: Prosveta].

Милошевић, Н. (1978). Антрополошки есеји. Београд: Нолит [Milošević, N. (1978). Antropološki eseji. Beograd: Nolit]. 
Милошевић, Н. (1990). Идеологија, психологија и стваралаштво. Београд: Белетра [Milošević, N. (1990). Ideologija, psihologija i stvaralaštvo. Beograd: Beletra].

Милутиновић, 3. (2009). „Предговор”, у Ками, А. Странаи. Београд: Завод за уџбенике и наставна средства: 7-10 [Milutinović, Z. (2009). „Predgovor”, u Kami, A. Stranac, Beograd: Zavod za udžbenike i nastavna sredstva: 7-10].

Николић, Љ., Милић, Б. (2007). Читанка за четврти разред средње школе. Београд: Завод за уџбенике и наставна средства [Nikolić, Lj., Milić, B. (2007). Čitanka za četvrti razred srednje škole. Beograd: Zavod za udžbenike i nastavna sredstva].

Сартр, Ж. П. (1981). Портрети. Београд: Нолит [Sartr, Ž. Р. (1981). Portreti. Beograd: Nolit].

Sartre, J. P. (1964). Egzistencijalizam je humanizam. Sarajevo: „Veselin Masleša”.

Солар, М. (1985). Мит о авангарди и мит о декаденцији. Београд: Нолит [Solar, M. (1985). Mit o avangardi i mit o dekadenciji. Beograd: Nolit]. Cakeljić, V. (1988). „Fransuska kratka priča”, u: Antologija kratke priče Francuske (prir. V. Cakeljić). Kruševac: Bagdala: 195-199.

Milan Gromovic

University in Novi Sad

Faculty of Philosophy, Department of Serbian Literature - Language and literature Module literature

milan.grom@gmail.com

\section{CAMUS' MEURSAULT IN THE CONTEXT OF ABSURD AND VAMPIRE METAPHOR - A METHODICAL APPROACH}

\section{Summary}

The paper presents one aspect of the teaching interpretation of Albert Camus' novel Stranger, which includes the analysis of the main character in the context of the philosophy of absurdity and vampire metaphors. In the introductory part, the context of existentialism as a philosophical direction and its foothold in Camus' novel are illuminated. A comparative analysis of the main character in the first and second parts of the novel is presented, with a special emphasis on the motif of light that initiates the story of Meursault as a vampire of the new age. A series of problem situations in which the main character is located and the proposed methods of a possible analysis in teaching is systematically presented. The work includes literary theoretical reflections of Jean-Paul Sartre, Nikola Milošević, as well as the methodical components necessary for the analysis of literary work in teaching. The paper presents examples of Meursault's fear of light, cross and priests. His lack of agreement with the laws of the real world shows the reader that he is a representative of the world of metaphysics, fantasy, and not the world with humanistic 
values. The paper opens a possible assumption that Meursault has a vampire connection at the level of metaphor. He is a stranger in the world of men, but he is indifferent to his death for he is not afraid of the world into which he will enter. His absurd relationship with other heroes is not only a negation of the system that the real world imposes, but also an indication that there is another world in which it would be better. The vampire metaphor is a good system of reading work and interpretation in teaching because it opens the possibilities of new interpretations and it shifts the context from existentialism to postmodern reading. The paper is divided into eight sections: Existentialism, Antinovel and Camus' philosophy of Absurd, Meursault in the first part of the novel, Vampire metaphor context, The necessity of committing crimes - the escape from hot light into saving darkness, Meursault in the second part of the novel, Problem of guilt and Meursault's relation to death and God.

Keywords: Albert Camus, Stranger, Meursault, absurd, vampire.

Примљено: 16. 5. 2019.

Прихваћено: 28. 8. 2019. 